GOURMETS IN THE LAND OF FAMINE 



\section{Gourmets in the Land of Famine}

THE CULTURE AND POLITICS OF RICE IN MODERN CANTON

Seung-joon Lee

STANFORD UNIVERSITY PRESS

STANFORD, CALIFORNIA 
Stanford University Press

Stanford, California

(C) 20I I by the Board of Trustees of the Leland Stanford Junior University. All rights reserved.

No part of this book may be reproduced or transmitted in any form or by any means, electronic or mechanical, including photocopying and recording, or in any information storage or retrieval system without the prior written permission of Stanford University Press.

Printed in the United States of America on acid-free, archival-quality paper Library of Congress Cataloging-in-Publication Data

Lee, Seung-joon, I970-

Gourmets in the land of famine : the culture and politics of rice in modern Canton / Seung-joon Lee.

p. $\mathrm{cm}$.

Includes bibliographical references and index.

ISBN 978-0-8047-7226-6 (cloth : alk. paper)

I. Rice trade-China-Guangzhou-History-2oth century. 2. Rice tradeGovernment policy-China-Guangzhou-History-2oth century. 3. RiceQuality-China-Guangzhou-History-2oth century. 4. Food supplyChina-Guangzhou-History—2oth century. I. Title.

HD9066.C573G835 20I I

$$
338 . \mathrm{I}^{\prime} 73 \mathrm{I} 8095 \mathrm{I} 275-\mathrm{dc} 22
$$

$$
2010024485
$$

Typeset by Bruce Lundquist in I0.5/I 2 Sabon 
To my parents:

Jong-yeon Lee Ok Yul Kim 
